\title{
Ayurveda iron preparations used in Sri Lanka
}

\author{
R. L. Jayakody', Damayanthi Withanage ${ }^{2}$ \\ The Ceylon Journal of Medical Science 1999; 42: 95-99
}

\begin{abstract}
Iron deficiency anaemia has a high prevalence in Sri Lanka. As ayurveda treattment is popular a proportion of patients with anaemia, especially the rural folk are treated with ayurveda haematinics. This descriptive study attempts to briefly review the ayurveda iron preparations and the bioavailability of iron from them. There are between 15 to 20 ayurveda iron preparations that are listed in the formularies. Of these Punarnavn Mandura Vati, Lnuha Asava and Chandraprabha Vati are three preparations that are commonly used. It is difficult to get at bioavailability and efficacy data of these preparations. A pilot study conducted in Sri Lanka has shown that Punarnava Mandura Vati has efficacy as a haematinic during pregnancy.
\end{abstract}

\section{Introduction}

Iron deficiency anaemia is a serious health problem in Sri Lanka. The Third National Nutrition and Health Survey conducted between October 1994 and January 1995 involving seven provinces (North and Eastern provinces excluded) has shown the prevalence of anaemia to be $45 \%$ amongst pre-school children, $58 \%$ amongst children between 5 and 10.9 years and $36 \%$ among adolescents. Among women, $45 \%$ non-pregnant and $39 \%$ of pregnant were anaemic. Prevalence of anaemia was most amongst non-pregnant mothers in the plantations $(59 \%)$ than those in the urban $(40 \%)$ and rural $(46 \%)$ areas. This means that a very high proportion of the rural population living in the villages are anaemic to varying degrees.

Sri Lanka has practitioners of Ayurveda spread throughout the country. Most villages have their own ayurveda practitioners who look after the health problems of the villagers. Due to the demand these practitioners have now expanded their services to semi urban and urban areas. State owned ayurveda hospitals and clinics are found spread throughout the country. Although exact figures are not available a fair proportion of the population (especially the rural population), seek ayurveda medicine for their health problems. This means that patients with iron deficiency anaemia are being treated by ayurveda practitioners.

While ayurveda practitioners use herbs and other remedies to treat symptoms of anaemia, the extent to which these practices complement preventive and therapeutic care provided by the Western system of medicine is not fully understood. Programmes designed to combat iron deficiency should also take into account the part played by the ayurveda sector. As part of in the Anaemia Control Project under the Ministry of Plan Implementation and Parliamentary Affairs we undertook to review the contribution of the ayurveda sector in the control of anaemia.

There are several questions that could be asked on the subject of ayurveda haematinics. For example we would want to know about the ayurveda iron preparations, extent of their use, manufacturers, consumption of haematinics, iron content and bioavailability, acceptability, compliance, adverse effects, cost etc. Because of the paucity of data in this field we restricted our inquiry to two areas given under the objectives.

\section{Objectives}

We attempted to answer the following two questions: 
1. What are the ayurveda iron preparations used in Sri Lanka?

2. What is the bioavailability of iron in them?

\section{Methods}

In order to answer these questions we had discussions with ayurveda practitioners and opinion leaders in the premier ayurvedic hospitals in Sri Lanka, including the Institute of Indigenous Medicine (IIM) and the Bandaranaike Memorial Ayurvedic Research Institute (BMARI). Scientists attached to the Universities and other institutes (e.g. Ceylon Institute of Scientific and Industrial Research (CISIR)) who had conducted research in this field were also consulted. Ayurveda formularies, journals and textbooks were perused.

Inquiries were also made from the teaching centres of ayurveda in India and from reputed local and Indian manufacturing houses. MEDLINE and internet searches were done using appropriate key words.

Lists of formularies, journals and textbooks consulted and the persons contacted, their addresses and contact numbers could be obtained from the authors.

\section{Results}

The information about the iron preparations was available in the formularies and the textbooks. We were also able to obtain some impressions from the discussions and the correspondence. However we were not successful in getting much information on this subject from India The searches of the databases also did not reveal any information.

\section{Ayurveda iron preparations used in Sri Lanka}

There are between 15 to 20 ayurveda iron preparations that are listed in the formularies and the books. Of these the following three preparations are widely used in Sri Lanka.

\section{i. Punanrava Mandura Vati -(powder made into tablets or pills)}

ii. Lauha Asava - (iron containing herbal wine)

iii. Chandraprabha Vati - (powder made into tablets or pills)

The following information about these three products are given in the Table 1 .

Sources of iron in the preparation

Composition (as per standard composition tables)

Method of preparation

Whether made daily or stored; shelf life etc.

Cost

Age group to which it is targeted

Method of administration (with food or fast ing etc.)

Recommended dose

Bioavailability of iron (if information is available)

The ayurveda haematinics containing metallic iron are generally not recommended in the pharmacopoeias for use on children. However it was revealed that both Punarnava Mandura Vati and Lauha Asava are given to children from year 4 upwards. Punanrava Mandura Vati and Lauhn Asavn are used exclusively for the management of anaemia (pandu). However Chandraprabha Vati is used for anaemia and for several other conditions as well (e.g. urinary tract infection).

These three haematinics are used in the ayurveda hospitals and clinics. There are a few individual practitioners who prepare the drugs themselves, but this component must be small. Several manufacturing houses manufacture them and sell in the open retail market. These drugs are also manufactured by the Sri Lanka Ayurvedic Drugs Corporation. This Corporation informed us that they sell about $500 \mathrm{~kg}$ of Punnrnava Mandura Vati and 17000 bottles (750 to $1000 \mathrm{~mL}$ per bottle) of Lauha Asava per year. There are about 7 or 8 such manufacturers. The sales figures from these manufacturing houses were not available. Considering the sales figures given by the Ayurvedic Drugs Corporation we may assume that the 
Table 1

Pharmacological information about three commonly used ayurvedic iron preparations

\begin{tabular}{|c|c|c|c|c|c|c|c|c|c|c|c|}
\hline 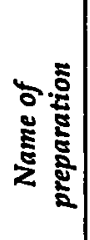 & $\begin{array}{l}\text { Source of } \\
\text { Iron }\end{array}$ & 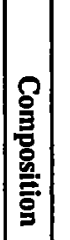 & $\begin{array}{c}\text { Method } \\
\text { of Prepration }\end{array}$ & 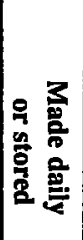 & $\begin{array}{l}\text { How it is } \\
\text { stored }\end{array}$ & 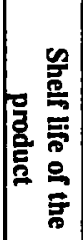 & Cost & $\begin{array}{c}\text { Age } \\
\text { group } \\
\text { targeted }\end{array}$ & $\begin{array}{c}\text { Method } \\
\text { of } \\
\text { administra- } \\
\text { tion }\end{array}$ & $\begin{array}{l}\text { Recom- } \\
\text { mended } \\
\text { dose }\end{array}$ & $\begin{array}{l}\text { Bioavail- } \\
\text { ability of } \\
\text { iron }\end{array}$ \\
\hline 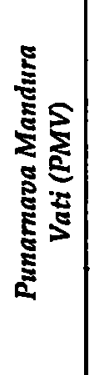 & $\begin{array}{l}\text { Iron rust or } \\
\text { impure oxide } \\
\text { from } \\
\text { blacksmith's } \\
\text { anvil purified } \\
\text { allowed to rust } \\
\text { giving } \\
\text { iron oxide }\end{array}$ & 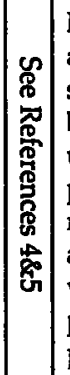 & $\begin{array}{l}\text { Mandura is purified } \\
\text { and incinerated by a } \\
\text { special method and } \\
\text { boiled in cow's urine } \\
\text { until it becomes a } \\
\text { paste. The products } \\
\text { mentioned in the recipe } \\
\text { are added and stirred } \\
\text { well. Tablets are } \\
\text { prepared from the } \\
\text { paste. }\end{array}$ & $\begin{array}{l}\frac{n}{0} \\
\frac{0}{2}\end{array}$ & $\begin{array}{l}\text { In glass vessels } \\
\text { as powder or } \\
\text { tablets; keep } \\
\text { away from } \\
\text { moisture }\end{array}$ & 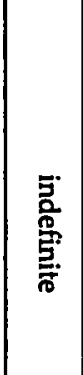 & $\begin{array}{l}1 \text { Rupee } \\
\text { per } 250 \mathrm{mg} \\
\text { tablet } \\
\text { approx. }\end{array}$ & $\begin{array}{l}\text { Adults } \\
\text { including } \\
\text { pregnancy, } \\
\text { do not use } \\
\text { below } 12 \\
\text { years }\end{array}$ & $\begin{array}{l}\text { Orally; with } \\
\text { lukewarm } \\
\text { water or with } \\
\text { decoction of } \\
\text { Tripala }\end{array}$ & $\mid \begin{array}{l}250 \mathrm{mg} \text { to } \\
500 \mathrm{mg} \\
\text { twice daily } \\
\text { before } \\
\text { meals. }\end{array}$ & $\begin{array}{l}\text { No } \\
\text { informa- } \\
\text { tion } \\
\text { available. } \\
\text { Probably } \\
\text { having } \\
\text { efficacy. } \\
\text { Assay for } \\
\text { iron 18 - } \\
22 \% w / w\end{array}$ \\
\hline 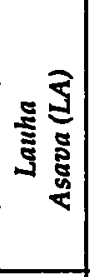 & \begin{tabular}{|l|} 
Iron filings or \\
sheets allowed \\
to rust \\
(Lauha \\
bhasma) \\
\end{tabular} & 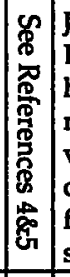 & $\begin{array}{l}\text { Jaggery and honey, } \\
\text { Lauha bhasma, other } \\
\text { herbal products are } \\
\text { mixed in water and the } \\
\text { vessel is sealed. After } \\
\text { one month the } \\
\text { fermented liquid is } \\
\text { strained. }\end{array}$ & 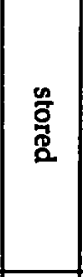 & $\begin{array}{l}\text { In dark } \\
\text { coloured glass } \\
\text { bottles } \\
\text { (air tight) }\end{array}$ & 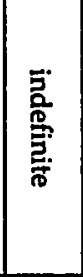 & $\begin{array}{l}\text { Rs. } 80 \text { to } 85 \\
\text { per } 750 \mathrm{ml} \\
\text { bottle. }\end{array}$ & \begin{tabular}{|l|} 
Adults \\
including \\
pregnancy \\
do not use \\
below 12 \\
years
\end{tabular} & $\begin{array}{l}\text { Orally; mixed } \\
\text { with equal or } \\
\text { double the } \\
\text { quantity of } \\
\text { water. }\end{array}$ & $\begin{array}{l}\text { Taken on } \\
\text { an empty } \\
\text { stomach } 20 \\
\text { ml }-30 \mathrm{ml} \\
\text { twice } \\
\text { daily. }\end{array}$ & $\begin{array}{l}\text { No } \\
\text { informa- } \\
\text { tion } \\
\text { available. }\end{array}$ \\
\hline 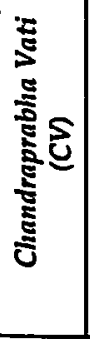 & $\begin{array}{l}\text { Iron filings } \\
\text { allowed to rust } \\
\text { (Lauha } \\
\text { bhasma) }\end{array}$ & 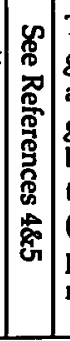 & $\begin{array}{l}\text { The ingredients (except } \\
\text { guggulu) are powdered } \\
\text { and mixed. Then } \\
\text { guggulu is added little } \\
\text { by little and pounded } \\
\text { till it mixes well. Vati } \\
\text { (pills), } 250 \mathrm{mg} \text { are } \\
\text { prepared from this } \\
\text { mixture. }\end{array}$ & $\frac{n}{0}$ & $\begin{array}{l}\text { In glass vessels } \\
\text { as powder or } \\
\text { tablets; keep } \\
\text { away from } \\
\text { moisture }\end{array}$ & 志: & $\begin{array}{l}\text { not } \\
\text { available }\end{array}$ & $\begin{array}{l}\text { Adults } \\
\text { including } \\
\text { pregnancy } \\
\text { do not use } \\
\text { below } 12 \\
\text { years } \\
\end{array}$ & $\begin{array}{l}\text { Orally; with } \\
\text { water, milk } \\
\text { and gingilly } \\
\text { powder; } \\
\text { besides } \\
\text { anaemia this } \\
\text { preparation is } \\
\text { used for } \\
\text { several other } \\
\text { conditions. } \\
\text { (eg. urinary } \\
\text { tract infections) }\end{array}$ & $\mid \begin{array}{l}\text { not } \\
\text { available }\end{array}$ & $\begin{array}{l}\text { No } \\
\text { informa- } \\
\text { tion } \\
\text { available. } \\
\text { Assay for } \\
\text { iron 4- } \\
6 \% w / w\end{array}$ \\
\hline
\end{tabular}


haematinics would be contributing only a small component (less than $5 \%$ ) to the total amount (ie. both Western and ayurveda haematinics) consumed.

The names of several other ayurvedic iron preparations that are listed in the formularies and books are given below. Our impression is that these are not used widely. The ingredients and the method of preparation are given in the references.

\section{Candanadi Lauha \\ 2. Dharti Lauha \\ 3. Pippalyadi Lauha \\ 4. Pradarantaka Lauha \\ 5. Pradarari Lauha \\ 6. Putapakva Visama Jvarantaka Lauha \\ 7. Rohitaka Lauha \\ 8. Sarvajuarahara Lauha \\ 9. Saptamrta Lauha \\ 10. Satvajuarahara Lauha \\ 11. Vidanga Lauha \\ 12. Vidangadi Lauha \\ 13. Yakrdari Lauha}

\section{How iron is used}

In ayurveda, iron is used in preparing medicines after purification (shodana) and incineration (bhasmikarana). There are several methods of purification and incineration. (ref. Rasa Ratna Samuchjaya) These methods convert the iron into iron oxide. Lauha (iron), yabora and kantha lauha (magnetic iron) are some forms of iron which are used in preparing the iron oxide. Shodana of lauha is done by heating it and immersing in a decoction of tripala (made out of the fruits of Terminalia chebula, Terminalia belerica and Phyllanthus emblica) or other suitable decoction. During bhasmikarna the lauha mentioned above is mixed with tripala and cooked on a fire. The lauha is ground and made into a fine powder. This process is repeated several times over several days. The iron powder is then ground with juice of Nelli (Phyll- antinus emblica) or the decoction of tripala and heated in a cow dung fire. The iron is placed inbetween two earthern ware pots during the heating. The heating is repeated several times. There are tests which can be done on this iron to ellsure that it is of a suitable quality. Yabora and kantha lauha are treated in the above mentioned method to get the iron oxide.

\section{Bioavaillability of iron in local ayurveda iron preparations}

We did not succeed in getting any information about the bioavailability of iron in the ayurveda iron preparations. Although it transpired that some of this work has been done in certain centres in India we were not able to get this information. When we inquired from the practitioners they gave the impression that these drugs are effective in the management of anaemia. We were able to trace the work of a local postgraduate student who studied the efficacy of Punarnavadi Mandura Vati in anaemia of pregnancy. In this study a randomized, placebo controlled design was used. Each group had 22 patients and they were treated with the ayurveda haematinic or placebo for 2 months. It was found that there was significant improvement in the symptoms of anaemia and in the concentrations of haemoglobin in the mothers who received the haematinic.

\section{Conclusions}

There is very little published information about the use of ayurveda haematinics in Sri Lanka. Ayurveda textbooks originating from India site over 20 preparations which are used to treat anaemia. Of these preparations Punanrava Mandura Vait, Lauha Asava and Chandraprabha Vati are used commonly in Sri Lanka. No bioavailability studies about the ayurveda haematinics were found.

The data from a local study suggests that Punarnavadi Mandura Vati is effective in the management of anaemia during pregnancy.

There is a need to get the published literature on bioavailability and efficacy of ayurveda haematinics. Studies could also be conducted locally to address these questions. 


\section{Acknowledgments}

We wish to thank all those who helped us by providing information, the librarian at the Institute of Indegenous Medicine (IIM), Dr. Suji Kottegoda for getting information from the Yakkala Ayurveda Institute, Dr. Shanthi and staff of the Department of Dravya Guna Vingnana at the IIM, staff of the Monitoring and Progress Review Division of the Ministry of Plan Implementation and Parliamentary Affairs.

\section{Bibliography}

1. Sharma PV, Charaka Samhitha, Vol 2, Ed 2, 1994 Chankhambha Orientalia, Varanasi, India.

2. Sri Pakshadharakuta, Asava - Arishta Vingnanaya (Sinhala Translation by A.Disanayake, Modern Book Company, Nugegoda, Sri Lanka. 1983.
3. Vidyabhushana $A B$, Bhaishajya Ratnawaliya, Mohila Press, Luchnov, India.

4. Ayurveda Aushada Sangrahaya, Vol 1, part 1, Department of Ayurveda, Colombo, Sri Lanka. 1976.

5. The Ayurveda Formulary of India, part 1, Ed I; Government of India, Ministry of Health and Family Planning, Department of Health.

6. M. Senadheera Garbhani Panduwa Wishayayehi Punarnavadi Mandura Vati Yedime Sapalyathawaya Adyayanaya Kirima (Study of Efficacy of Punarnavadi Mandura Vati in Anaemia of Pregnancy) M.Phil Thesis submitted to the University of Colombo through the Institute of Indigenous Medicine, 1995.

7. Mudalige R, Nestel P. Prevalence of anaemia in Sri Lanka. Ceylon Journal of Medical Science 1996; 39: 9-16. 